Anthropologie \& développement

\& développemen

45 | 2017

La fabrique de l'action publique dans les pays 'sous régime d'aide'

\title{
Looking at Public Policy in Africa
}

Introduction

Philippe Lavigne Delville

\section{CpenEdition}

\section{Journals}

Electronic version

URL: http://journals.openedition.org/anthropodev/541

DOI: 10.4000/anthropodev.541

ISSN: 2553-1719

Publisher

APAD - Association pour l'anthropologie du changement social et du développement

Printed version

Date of publication: 1 May 2017

Number of pages: $23-32$

ISBN: 979-10-93476-04-9

ISSN: 2276-2019

\section{Electronic reference}

Philippe Lavigne Delville, «Looking at Public Policy in Africa », Anthropologie \& développement [Online] 45 | 2017, Online since 01 November 2017, connection on 19 April 2019. URL : http:// journals.openedition.org/anthropodev/541 ; DOI : 10.4000/anthropodev.541

La revue Anthropologie \& développement est mise à disposition selon les termes de la Licence Creative Commons Attribution 4.0 International. 


\title{
Looking at Public Policy in Africa
}

\author{
Introduction
}

Philippe Lavigne Delville

What does it mean to speak of public action and public policy ${ }^{1}$ in Africa and more broadly in countries "under an aid regime" where international aid, its institutions and its funding play a structuring role? Does looking at development policies and interventions long-studied by the socioanthropology of development through the lens of public policy provide new insight?

Titled "The Making of Public Action in Countries 'Under an Aid Regime'", APAD's $12^{\text {th }}$ international conference ${ }^{2}$ aimed to debate these questions, both by gathering recent research on classic topics in the socioanthropology of development (local-scale development interventions, public and collective services, etc.) and by exploring still-new subjects such as how aid policies and national public policies are produced and negotiated. It also aimed to de-compartmentalise research on these topics, between the socio-anthropology of development, the political sociology of public policy, and political science.

This special issue begins the publication of the conference's papers and explores the issue of public policy and public action in Africa.

\footnotetext{
${ }^{1}$ French political scientists speak of "public action" to describe multi-stakeholder processes of policy design and implementation, in order to highlight the shift from the state-centered concept of public policy that prevailed in policy process analysis until the 1990s. This distinction is not very useful in English where there was no such confusion between state policy and public policy. I will however sometime use "public action" for international and/or NGOs initiatives.

${ }^{2}$ This conference took place in Cotonou from November 19 to 21, 2015, in partnership with the University of Abomey Calavi's Laboratoire d'Analyse des Dynamiques de Développement (LADYD), the Laboratoire d'Études et de Recherche sur les Dynamiques Locales (LASDEL), the University of Abomey Calavi and the Institut de Recherche pour le Développement (IRD).
} 
Development Policies, Development Projects: Internationalised and Extraverted Public Action

The socio-anthropology of development has mainly studied development projects, taking an interest in public policies as such only in the past few years.

Development projects have, since the colonial era, been the favoured mode of state intervention. Colonial intervention was an "archipelago" form that concentrated on areas deemed useful (urban centres, zones developed for irrigation, cash crop areas) and in which "development" was entrusted to public or semi-public development companies in what was already a "two-speed administration" (Blundo, 2011).

Launched during the New Deal era, the Tennessee Valley Authority in the United States is the (very empirical at first; see Hargrove, 1994) archetype of integrated regional development projects (Garel, 2003). It would be the model for colonial "development" projects in the 1950s. The independent States multiplied such projects, which were entrusted to regional development companies before they were disqualified for their ineffectiveness and cost to the national budget, right before the structural adjustments, and then almost entirely abandoned thereafter. James Scott (1998) would call this mixture of technocratic pursuit of the rationalisation of societies and nature and authoritarian powers "high modernism".

Development projects were thus originally a government policy instrument, entrusted to government institutions. Projects, as they developed in the 1990s-2000s, are on the contrary an integral part of the specific post-adjustment context in which the State was marginalised and in which donors' policies and projects were removed from the government and practically replaced national policies (Naudet, 1999). It is this phase that corresponds to the (sometimes disorganised) multiplication of projects of all sorts, the generalisation of short-term funding and the principle of competition, the systematisation of project management tools and finally the spread of this bureaucratic culture of project management to local governments, farmers' organisations and national NGOs.

Development projects as substitutes for national policies were themselves questioned starting in the 2000s: the unwanted effects of this 
multiplication of projects had become unmanageable; seeking to renew their legitimacy after the "aid fatigue" that followed the fall of the Berlin wall, aid institutions once again gave States a prime role and claimed to act in support of national policies. Appropriation and ownership (Raffinot, 2010) became watchwords. The Paris Declaration endorsed this doctrine shift, which was only partially reflected in changes in practices (Wood, Betts, Etta et al., 2011).

Henceforth, with a new swing of the pendulum, programme aid, basket funding (supporting sectoral policies) and even budgetary aid (either sectoral or not) (Arnal, 2007) are being promoted. Donors tend to coordinate their work around multi-annual programmes combining strategic and institutional objectives and quantitative targets when it comes to outcomes. They are lowering their direct funding to NGOs for implementing their own projects in the field, increasing the share allocated to advocacy or experimentation on the one hand and pushing NGOs to act as sub-contractors for the implementation of national programmes on the other.

This return to public policies is, however, taking place under strict constraints. They must be approved by donors and comply with macroeconomic frameworks in what Bergamaschi (2008) calls "donordriven ownership". The Millennium Development Goals and Paris Declaration enshrine a "co-responsibility" of States and donors that leads to an "increasing entanglement of donor institutions and recipient administrative systems" (Whitfield and Fraser, 2009: 19). A large share of public policy design and implementation is produced through highly internationalised and multi-positioned national stakeholders (Diallo, 2012). Line ministries have recovered greater control over policies, but financing mechanisms continue for the most part to follow specific procedures-and attempts to couple national procedures and donors' procedures often lead to the "co-production of delays" (Blundo, 2015). Even more, because they now have to follow national financial procedures, donors push for a restructuring of the procedures and modalities of public administration, thus accentuating their interference with the very core of how States operate (Raffinot and Samuel, 2006).

In this model, projects do not disappear; they remain a favoured mode of policy implementation within national-scale programmes. 
Managerialisation is not threatened, quite the contrary. Within this internationalised governance, configurations are diverse. Alongside these programmes (10-year education programme, etc.), some sectors involving global problems such as major endemics are addressed through specific schemes, which are largely transnational, such as the Global Fund to Fight AIDS, Tuberculosis and Malaria (Eboko, 2015).

Since the start of the 2000s, African countries have been in a position of assumed coproduction of public action by States and donors (and sometimes international NGOs), enshrining and institutionalising the limited sovereignty of governments in ambiguous forms of internationalised governance. Specific configurations vary, however (Fraser and Whitfield, 2009). Managing aid dependency is, for Bayart, a matter of extraversion strategies, which have historically been a mode of articulation between African elites and the rest of the world (Bayart, 1999). Donors' ability to impose their visions is under debate. Donors themselves are prisoners of a game in which they need to spend money to exist and in which time plays against them. In addition, focusing one's sight on aid throws a shadow on the political strategies that play out through, and sometimes under, these policy negotiation processes. Analysing the production of land policy in Uganda (Gay, 2016) thus reveals how the central powers must negotiate with regional political elites and parliament, in complex, highly political processes in which aid, its frameworks and its experts are ultimately very little present.

In different areas, we see attempts by government institutions to maintain or recover control over strategic resources, challenge decentralisation policies, or transfers of power and resources that had been set up under the strong influence of aid at the height of State weakness $^{3}$. In addition, State action is not limited to aid-related sectors. In coordination with, substitution for or opposition to the actions of government institutions, other national or international stakeholders are taking up the definition and handling of problems seen as public or collective. In short, acknowledging that public action is a multistakeholder, internationalised and extraverted affair forces one to

${ }^{3}$ On wildlife in Tanzania, see Benjaminsen, Goldman, Minwary et al., 2013. 
examine empirically the political and institutional configurations, the stakeholders in play and their relationships, and the controversies and stakes, and explore these ambiguous modalities of coproduction of public action in countries "under the aid regime".

\section{Public Policy, Public Action and Governability: the Special Issue}

Worldwide, the neoliberal shift has displaced the relationships between the State, private sector and associative sector in the production and implementation of public policies, relationships that were based on very different models depending on States' political trajectories. The private and associative sectors' contribution is more strongly valued. Managerial thinking is on the rise. Such recompositions are not specific to African countries, even if the forms they take are partially specific because of their political and institutional histories and because of the prevalence of international aid.

The four papers in this special report explore various facets of the issue of public policy and action in Africa. Starting from the overarching topic of the symposium, Philippe Lavigne Delville advocates for a socioanthropology of public action in countries "under the aid regime". For him, such a perspective simultaneously confirms and expands issues dealt with by the socio-anthropology of development. What we call development policies or actions, he says, are largely in the realm of what is elsewhere referred to as public policy and the social and non profit sector. Shifting the focus from "development" to public policy allows for a new look at this largely extraverted public action; it allows one to better distinguish, within gaps and contradictions, what has to do with the structural contradictions in public policies and what has to do with the political and institutional configurations specific to countries under an aid regime. Multiple stakeholders, inter-institutional struggles, ungovernability issues linked to the mushrooming of public policy stakeholders are, indeed, global processes. Analysing development in terms of public policy also leads one to examine more fully the areas upstream from policies and projects: how international frameworks are produced; the processes by which national public policies are produced and designed, in a mix of policy (sectoral policy), politics (struggles for power) and polity (social contract) issues, and 
through national and international actors. This provides a new vision both of these forms of internationalised governance that take place in Africa and of the policy/politics issues in Africa. Such a perspective, asserts Lavigne Delville, requires-and benefits from-a critical dialogue with the political sociology of public policy, which has developed relevant concepts and analytical tools, even though they obviously cannot be imported in African contexts without critical testing.

Introducing policy process studies to an APAD audience is the goal of the second article in this special issue. Based on his own research and on the keynote speech that he gave during the conference, Philippe Zittoun presents a "pragmatic" approach to public action. He examines the processes by which policy statements are formulated and spread, and by which stakeholders defending stakes attempt to bring together problems and solutions so that problems can be tackled. He shows the importance of this definition and argumentation work, which is inherent to public policy, and the importance to be given to discursive practices and discourse in action. He shows the extent to which this process-even when it borrows technicised discourse-is profoundly political. Philippe Zittoun replaces this approach in a panorama of research in political science and the political sociology of public policy, showing the splintering of this field into multiple currents, illustrating the specificity of "policy process" research, which seeks, not to offer decision-makers solutions, but to clarify processes themselves. He highlights the key concepts put forth during the history of the discipline. Well beyond a defence and illustration of his own approach, this paper is also an introduction to this field of research and its diversity and fertility.

The following articles illustrate two facets of public action in Benin. Issifou Abou Moumouni provides a contribution to the discussions on the coproduction of public action by heterogeneous stakeholders (Olivier de Sardan, Abdelkader, Diarra et al., 2011): he examines the collaborations that have been institutionalised between law enforcement and associations of hunters in north-eastern Benin. During the 1990s, hunters, a traditional brotherhood in rural societies in the African savannah, formed associations to fight criminality. They are regularly called upon by law enforcement in the fight against banditry and in particular highway robbers. Their knowledge of the bush and their capacity to face danger 
make them valuable helpers, and they see themselves as such. For approximately twenty years, co-production of security has taken place, mobilising government actors and non-state actors, with the latter completing the actions of the police in contexts in which the latter cannot act. The semi-unofficial nature of their intervention also allows members of hunters' associations to free themselves of the constraints weighing on law enforcement and hunters are reputed to have been responsible for extra-legal executions of highway bandits under the disguise of selfdefence during attacks. The government authorities value the hunters' contribution to public safety and urge them to turn suspects into the police, while covering up the illegal practices that supplement their own limits. Far from reflecting a weakening of the State, these forms of coproduction are, for Issifou Abou Moumouni, a local State-building strategy.

Héloïse Valette, Fabrice Gangneron and Alain Bonnassieux examine the production of a sectoral policy-the rural and periurban drinking water policy in Benin. In this sector, the Dublin Conference enshrined, in 1994, the commercial principle: water services must self-finance via the sale of water. This principle was transcribed into the Beninese national policy a few years later, at the start of the 2000s, and called into question the prior institutional framework of "community management". Yet, international doctrines do not translate automatically (Delpeuch, 2009). With each change of scale, the policy principles are translated and reformulated, and the stakes-as well as the stakeholders-vary. The reform of Benin's drinking water sector was similar to what happened, at roughly the same time, in neighbouring countries: local government responsibility for service and delegation of implementation to private organisations. However, the Water Ministry executives imposed a restrictive vision of private stakeholders, highlighting private entrepreneurs and rejecting the slight legal opening for delegation of management to users' associations. They fought to maintain centralised calls for tender for the laying down of new water supply mains and thus conserve control over financial means, in practice lowering local government's prerogatives. On the local scale, the institutional reorganisation required communes to recover ownership of existing equipment, to the detriment of village organisations that managed them until reform. To ensure that the fees owed to them were paid, they limited the duration of delegation contracts, threatening profitability for entrepreneurs. In this way, we saw partial reconfigurations of the water 
service, which varied greatly from one commune to another, while delegation to entrepreneurs did not truly resolve the service quality issues that had been highlighted to criticize community management.

Models transferred by donors and reinterpreted by countries, the political stakes of reforms in terms of the relationship between the State and local governments and the power of sectoral administration, coproduction of public action with non-State stakeholders: both of these papers illustrate important facets of public policy and public action in Africa, and the relationships between government institutions and nonState institutions, both national and international. They raise the question of the nature of this little-regulated multi-stakeholder governance and the governability issues it raises. Other dimensions will be explored in an upcoming issue of Anthropologie \& développement: local governance of services and the competition and complementarity between stakeholders on the local scale, social mobilisations and betting on reform agendas, the interplay of reciprocal instrumentalisations between the State and donors, the publicisation of issues by stakeholders outside aid, etc.

\section{Bibliography}

ARNAL J.-F., 2007, " Comment la mise en oeuvre de la Déclaration de Paris a servi de tremplin à la réforme du processus d'aide budgétaire globale au Ghana », Afrique contemporaine, 223-224(3-4) : 325-339.

BAYART J.-F., 1999, "L'Afrique dans le monde: une histoire d'extraversion", Critique internationale, 5(1) : 97-120.

BENJAMINSEN T.A., GOLDMAN M.J., MINWARY M.Y. et al., 2013, "Wildlife Management in Tanzania: State Control, Rent Seeking and Community Resistance ", Development and Change, 44(5) : 1087-1109.

BERGAMASCHI I., 2008, Mali : Patterns and Limits of Donor-driven Ownership, Global Economic Governance Program Working Papers n 41, Oxford, University College, $39 \mathrm{p}$.

BLUNDO G., 2011, « Une administration à deux vitesses. Projets de développement et construction de l'État au Sahel ", Cahiers d'études africaines, 202203(2-3) : 427-452. 
BLUNDO G., 2015, La coproduction du retard. Anthropologie de l'aide budgétaire au Cameroun et au Niger, Paris, Agence française de développement, $45 \mathrm{p}$.

DELPEUCH T., 2009, "Comprendre la circulation internationale des solutions d'action publique: panorama des policy transfer studies ", Critique internationale, 43(2) : 153-165.

DIALLO R.N., 2012, "Élites administratives, aide internationale et fabrique de l'action publique de la conservation au Mozambique ", Politique africaine, 126(2) : 143-161.

EBOKO F., 2015, Vers une matrice de l'action publique en Afrique ? Approche transsectorielle de l'action publique en Afrique contemporaine, Questions de Recherche / Research Question $n^{\circ} 45$, CERI, 40 p.

FRASER A. and WHITFIELD L., 2009, «Understanding Contemporary Aid Relationship ", in Whitfield L. (ed.), The Politics of Aid, Oxford, Oxford University Press : 74-107.

GAREL G., 2003, Le management de projet, Coll. Repères, Paris, La Découverte.

GAY L., 2016, À la recherche de l'hégémonie: la fabrique très politique des politiques publiques foncières en Ouganda sous le régime du National Resistance Movement (NRM), entre changement et inertie, Doctorat en science politique, université de Montpellier, Montpellier, $764 \mathrm{p}$.

HARGROVE E.C., 1994, Prisoners of myth: The leadership of the Tennessee Valley Authority, 1933-1990, Princeton, Princeton University Press.

NAUDET D., 1999, Trouver des problèmes aux solutions. Vingt ans d'aide au Sahel, Paris, OCDE.

OLIVIER DE SARDAN J.-P., ABDELKADER A., DIARRA A. et al., 2011, Gouvernance locale. La délivrance de quatre biens publics dans trois communes nigériennes, Études et Travaux $n^{\circ}$ 95, Niamey, LASDEL, $39 \mathrm{p}$.

RAFFINOT M., 2010, "L'appropriation (ownership) des politiques de développement: de la théorie à la pratique ", Mondes en développement, 149(1) : 87-104.

RAFFINOT M. and SAMUEL B., 2006, « Les cadres de dépenses à moyen terme : un instrument utile pour les pays à faible revenu ? ", Statéco, $100: 105-120$.

SCOTT J., 1998, Seeing like a State. How Certain Schemes to Improve the Human Condition Have Failed, New Haven \& London Yale University Press. 
WHITFIELD L. and FRASER A., 2009, "Introduction: Aid and Sovereignty ", in Whitfield L. (ed.), The Politics of Aid, Oxford, Oxford University Press : 126.

WOOD B., BETTS J., ETTA F. et al, 2011, L'évaluation de la Déclaration de Paris, phase 2, rapport final, Copenhague, Institut danois d'études internationales, $251 \mathrm{p}$.

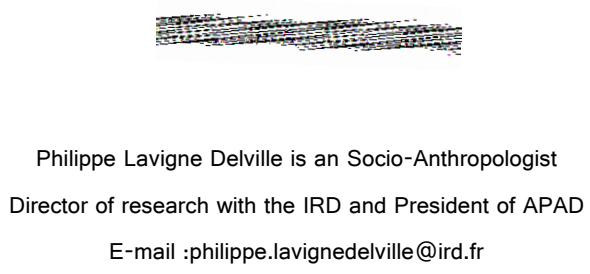

E-mail :philippe.lavignedelville@ird.fr 